\title{
Development of cambioxylophagous insect fauna on blue spruce after chemical thinning
}

\author{
E. Kula, R. Kajfosz, J. Polívka
}

Faculty of Forestry and Wood Technology, Mendel University in Brno, Zemédélská 3, CZ-61300

\begin{abstract}
Kula, E., Kajfosz, R, Polívka, J. 2013: Development of cambioxylophagous insect fauna on blue spruce after chemical thinning. - Beskydy, 6 (2): 117-126

Chemical thinning performed in stands of blue spruce (Picea pungens) in air-polluted areas of the Ore Mountains does not pose a significant threat of sub-bark pest outbreaks. Application of the herbicide Roundup in autumn and in spring caused dieback of the treated trees where mainly Hylurgops palliatus became active and completed its development. Pests Ips amitinus and Pityogenes chalcographus died mostly at larval stage, despite their high abundance. Cryphalus abietis completed its development only on thicker branches and was not able to occupy tops of trees due to fast dieback of phloem. Quality of phloem was strongly affected by the speed of defoliation.
\end{abstract}

Keywords: herbicide Roundup, chemical thinning, Picea pungens, Hylurgops palliatus, Ips amitinus, Pityogenes chalcographus, Ore Mountains

\section{Introduction}

Stands of substitute tree species with a high share of blue spruce (Picea pungens Engelm.) were planted at the beginning of the 1980s during regeneration of forests on clearcuts induced by air pollution, mainly in the area of the Ore Mountains (Kubelka et al. 1992, Šika 1976, Tesař 1981, Balcar 1986, Jirgle et al. 1983). Thirty years later when air-pollution decreased and site conditions improved, forest regeneration with target species began (Picea abies /L./ Karst., Fagus sylvatica L., Abies alba Mill., Acer pseudoplatanus L.), benefiting from the existing substitute tree stands (shading, microclimate) (Šrámek et al. 2008). One of the possibilities of site preparation for regeneration is elimination of blue spruce by chemical thinning (Pop et al. 2010). The objective is fast killing of the standing trees, accompanied by intensive defoliation, opening up of the stand and gradual disintegration of the treated trees. In such conditions, the newly established stand is protected from temperature fluctuations, especially from late frosts.
After such sudden loss of assimilatory apparatus while the root system is still vital, quality of blue spruce phloem changes differently than in case of natural dieback when needles are shed very gradually, even after the root system had died (Kula et al. 2009). This is connected with the presumption that the synusia of cambioxylophagous insects will be limited by phloem quality, both in its species composition and attack intensity. On naturally dying blue spruces with Dendroctonus micans (Kug.) as the inciting mortality factor, the dominant species is Ips amitinus (Eichh.); however, on suddenly killed spruces we expect to see characteristic changes not only in phloem quality, but also in the sub-bark fauna composition. In Norway spruce, similar change has been observed on stems of trees struck by lightning (Kula, Ząbecki 1997), trees killed by air-pollution (Kudela, Wolf 1963) or on standing stems of trees with broken-off whole crown (Kula et al. 2006) with dominant occurrence of Xyloterus lineatus (Oliv.), Polygraphus poligraphus (L.), Hylurgops palliatus (Gyll.) and Isarthron fuscum (Fabr.), or on windfalls (Kula, Ząbecki 2006a, 2006b). 
Hypothesis: The course of blue spruce (P. pungens) dieback will be differentiated according to the method of application and concentration of the herbicide (Roundup). Speed of dieback and the induced change of phloem quality will affect the synusia of sub-bark and wood-destroying fauna in the treated blue spruces as well as the level of development completion.

Objective: To determine cambioxylophagous insect fauna and to assess the danger of bark beetle outbreaks in blue spruce stands after chemical thinning.

\section{Material and Methods}

Blue spruces (173 ind.) killed by Roundup Klasic (Glyphosate-IPA $480 \mathrm{~g} \cdot \mathrm{l}^{-1}$ ) were felled (for details see Pop et al. 2010) (average diameter at breast height (DBH) $13.3 \pm 2.85 \mathrm{~cm}$, average height $8.02 \pm 1.21 \mathrm{~m}$ and average crown base height $2.49 \pm 0.75 \mathrm{~m}$ ). Bark was removed from stems and branches and occurrence of cambioxylophagous species was determined from the presence of typical galleries (eventually imagos and larvae) along the whole profile of the stem and crown branches in one-meter connecting sections. In each of the bark beetle species found on a section, the following parameters were determined: stage of development (larva, pupa, imago and larval mortality according to gallery development), gallery development stage (entrance hole, nuptial chamber, mother and larval galleries, exit holes), intensity of the attack (scattered attack - sporadic occurrence of feeding marks on the examined section; increased attack - feeding marks occupy $1 / 3-2 / 3$ of the section surface; heavy attack - feeding marks occur on more than $2 / 3$ of the section surface) (Kula, Ząbecki 1996) and the stage of phloem dieback (up to 20\%: phloem is vital, peelable in long stripes, water loss is little, phloem fibres may get caught on knife during cutting; 30-50\%: phloem and stripes of bark are not so easy to peel, only in short segments, moderately dry; 60-80\%: phloem of darkening colour cannot be peeled, only cut off; 90-100\%: phloem is dark, dying or dead, content of water is insufficient for survival of cambioxylophagous insects. Diameter of each section was measured in its mid-length and its volume was calculated. For objective evaluation, sections were grouped according to their volume class [ $<0.99 \mathrm{dm}^{3}$ (VC_1); $1-2.49$ (VC_2); 2.5-4.99 (VC_3); 5-7.49 (VC_4); 7.5-9.99 (VC_5); 10-14.99 (VC_6); 15-24.99 (VC_7); > $25 \mathrm{dm}^{3}$ (VC_8)].

The effect of chemical thinning and nature conditions on the cambioxylophagous fauna of blue spruce was tested using the Canoco for Windows 4.5 (TerBraak, Šmilauer 2002) program. To depict diagrams we used the CanoDraw for Windows program. The statistical significance of particular variables was tested by a MonteCarlo permutation test (999 permutations).

\section{Results}

Nine cambioxylophagous species were found on blue spruces after chemical thinning performed by different methods of herbicide (Roundup) application. On the 173 analyzed trees, three insect species showed eudominant position: H. palliatus (68.4\%), Pityogenes chalcographus (L.) (51.2\%) and I. amitinus (37.9\%). Simultaneously, larvae of the Cerambycidae family developed on stems and trees were also attacked by X. lineatus, Cryphalus abietis (Ratz.), Dryocoetes autographus (Ratz.), Hylecoetus dermestoides (L.) and Pissodes sp.

With gradual phloem drying and dieback, faunistic richness increased. Presence of some species was confirmed even in relatively fresh phloem; on stems with phloem dieback above $30 \%$, I. amitinus and P. chalcographus showed balanced dominance while development of $\mathrm{H}$. palliatus culminated at phloem dieback exceeding $50 \%$ (Tab. 1).

Tree size characterized by diameter at breast height (DBH) indicated logical regularity in distribution of dominant species. Competitive environment leads to decrease of $H$. palliatus and increase of I. amitinus with increasing DBH. P. chalcographus preferred thinner stems, in contrast to Isarthron genus (Cerambycidae) (Tab. 2).

Butt parts of trees were most attractive for the species H. palliatus (43.6\%), which decreased along the stem profile. The highest share was found in $4^{\text {th }}-8^{\text {th }}$ volume class $\left(5-25+\mathrm{dm}^{3}\right)$ when DBH was not a significant factor. P. chalcographus developed on medium to thin sections with volume up to $10 \mathrm{dm}^{3}$. Along the stem profile, it occurred mainly from the $3^{\text {rd }}$ height meter up to the tree top (14.8-24.7\% of the attacked sections); the most attractive were trees with $\mathrm{DHB}<100 \mathrm{~mm}$. I. amitinus occupied all volume and height sections along the tree profile with the $2^{\text {nd }}-6^{\text {th }}$ volume class being the most attractive. Cerambycidae dominated the butt section $(30.7 \%)$ and their abundance decreased with height (Tab. 2, 3, Fig. 1).

The highest mortality of blue spruce was achieved when herbicide was applied with a hypo-hatchet both in X/2009 and VI/2010 or by drilling in VI/2007; application with a brush onto chain-saw cuts was less effective. Low 
Tab. 1: Cambioxylophagous fauna on stems of dying blue spruces at the current stage of phloem dieback.

\begin{tabular}{lcrrrr}
\hline \multicolumn{7}{c}{ Degree of phloem dieback (\%) } \\
\hline \multicolumn{1}{c}{ Species } & $\mathbf{0 - 2 0}$ & $\mathbf{3 0 - 5 0}$ & $\mathbf{6 0 - 8 0}$ & $\mathbf{9 0 - 1 0 0}$ & N-sections \\
\hline Cerambycidae & 2.06 & 6.52 & 10.05 & 9.14 & 119 \\
Cryphalus abietis & 0.00 & 0.00 & 0.91 & 0.43 & 6 \\
Dryocoetes autographus & 0.00 & 0.00 & 1.37 & 0.11 & 4 \\
Dendroctonus micans & 0.00 & 0.00 & 0.46 & 0.00 & 1 \\
Hylecoetus dermestoides & 0.00 & 0.00 & 0.00 & 0.21 & 2 \\
Hylurgops palliatus & 2.06 & 15.94 & 38.81 & 31.46 & 405 \\
Ips amitinus & 6.19 & 17.39 & 16.44 & 19.45 & 249 \\
Pityophthorus pityographus & 0.00 & 0.72 & 0.00 & 0.00 & 1 \\
Pissodes sp. & 0.00 & 0.00 & 0.46 & 0.11 & 2 \\
Pityogenes chalcographus & 2.06 & 14.49 & 17.35 & 17.75 & 227 \\
Xyloterus lineatus & 0.00 & 1.45 & 4.57 & 3.08 & 41 \\
No attack & 87.63 & 53.62 & 28.31 & 37.62 & 575 \\
\hline N-sections & 97 & 138 & 219 & 941 & \\
\hline
\end{tabular}

Tab. 2: Cambioxylophagous fauna on stems of blue spruces after herbicide application (Roundup) according to diameter at breast-height (DBH) (\%).

\begin{tabular}{lrrrrrr}
\hline \multicolumn{1}{c}{ Species/ DBH (mm) } & $\mathbf{6 7 - 9 9}$ & $\mathbf{1 0 0 - 1 2 4}$ & $\mathbf{1 2 5 - 1 4 9}$ & $\mathbf{1 5 0 - 1 7 4}$ & $\mathbf{1 7 5 - 2 0 2}$ & Sum \\
\hline Cerambycidae & 5.60 & 6.25 & 7.16 & 10.07 & 17.09 & 8.49 \\
Cryphalus abietis & 0.80 & 0.00 & 0.67 & 0.00 & 1.27 & 0.43 \\
Dryocoetes autographus & 0.80 & 0.00 & 0.67 & 0.00 & 0.00 & 0.29 \\
Dendroctonus micans & 0.00 & 0.26 & 0.00 & 0.00 & 0.00 & 0.07 \\
Hylecoetus dermestoides & 0.80 & 0.00 & 0.22 & 0.00 & 0.00 & 0.14 \\
Hylurgops palliatus & 37.60 & 34.64 & 24.61 & 28.47 & 20.89 & 28.89 \\
Ips amitinus & 7.20 & 13.54 & 21.70 & 22.57 & 16.46 & 17.76 \\
Pityophthorus pityographus & 0.00 & 0.26 & 0.00 & 0.00 & 0.00 & 0.07 \\
Pissodes sp. & 0.00 & 0.00 & 0.00 & 0.69 & 0.00 & 0.14 \\
Pityogenes chalcographus & 35.20 & 17.45 & 17.45 & 11.11 & 3.80 & 16.19 \\
Xyloteruslineatus & 2.40 & 3.65 & 2.24 & 2.08 & 5.06 & 2.92 \\
No attack & 28.80 & 38.80 & 35.12 & 55.56 & 46.20 & 41.01 \\
\hline N-sections & 125 & 384 & 447 & 288 & 158 & 1402 \\
\hline
\end{tabular}




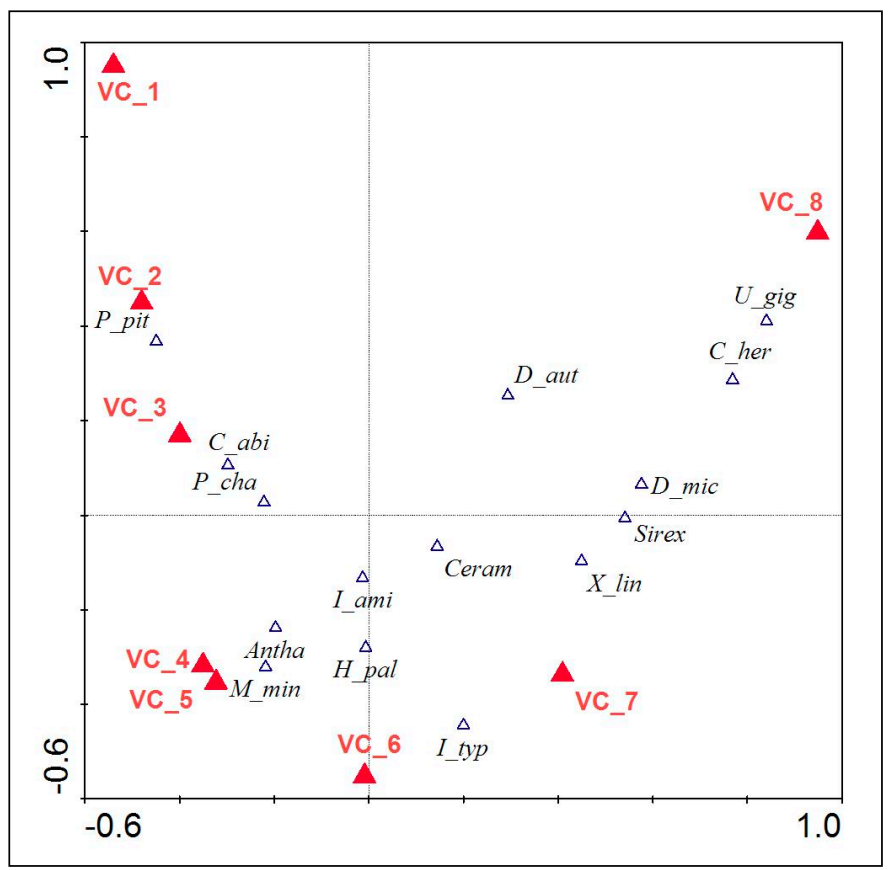

Fig. 1: Cambioxylophagous fauna of blue spruce stems after herbicide application (Roundup) according to volume classes (VC_1-VC_8) (see chapter Material and Methods and Tab. 3).

Tab. 3: Cambioxylophagous fauna of blue spruces after herbicide application (Roundup) according to volume class (\%).

\begin{tabular}{|c|c|c|c|c|c|c|c|c|c|c|}
\hline Species/Volume classes & 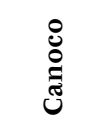 & $\begin{array}{l}\hat{\sigma} \\
\hat{0} \\
1 \\
0\end{array}$ & $\begin{array}{l}\stackrel{g}{+} \\
\stackrel{i}{1} \\
-1\end{array}$ & 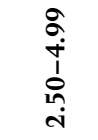 & $\frac{q}{\stackrel{+}{+}}$ & 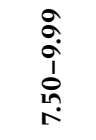 & $\begin{array}{l}\stackrel{a}{a} \\
\dot{ \pm} \\
\stackrel{1}{0}\end{array}$ & $\begin{array}{l}\stackrel{a}{a} \\
\stackrel{+}{+} \\
\stackrel{1}{1} \\
\stackrel{n}{n}\end{array}$ & 志 & $\underset{\Xi}{\xi}$ \\
\hline Cerambycidae & Ceram & 0.00 & 0.00 & 2.65 & 6.18 & 9.87 & 10.96 & 24.04 & 38.46 & 8.49 \\
\hline Cryphalus abietis & C_abi & 1.55 & 0.00 & 0.00 & 0.56 & 0.00 & 0.46 & 0.00 & 0.00 & 0.43 \\
\hline Dryocoetes autographus & D_aut & 0.00 & 0.00 & 0.00 & 0.00 & 0.66 & 0.46 & 1.09 & 0.00 & 0.29 \\
\hline Dendroctonus micans & D_mic & 0.00 & 0.00 & 0.00 & 0.00 & 0.00 & 0.46 & 0.00 & 0.00 & 0.07 \\
\hline Hylecoetus dermestoides & H_der & 0.00 & 0.00 & 0.00 & 0.00 & 0.66 & 0.00 & 0.55 & 0.00 & 0.14 \\
\hline Hylurgops palliatus & H_pal & 6.59 & 12.87 & 22.22 & 37.64 & 40.79 & 45.66 & 42.62 & 32.69 & 28.89 \\
\hline Ips amitinus & I_ami & 8.91 & 25.73 & 28.57 & 25.84 & 19.74 & 14.61 & 9.29 & 5.77 & 17.76 \\
\hline Pityophthorus pityographus & P_pit & 0.00 & 0.00 & 0.53 & 0.00 & 0.00 & 0.00 & 0.00 & 0.00 & 0.07 \\
\hline Pissodes sp. & Pisso & 0.00 & 0.00 & 0.00 & 0.00 & 0.66 & 0.00 & 0.55 & 0.00 & 0.14 \\
\hline Pityogenes chalcographus & P_chal & 18.99 & 37.43 & 27.51 & 18.54 & 12.50 & 4.11 & 0.55 & 0.00 & 16.19 \\
\hline Xyloterus lineatus & X_lin & 0.39 & 0.00 & 0.00 & 0.56 & 3.29 & 5.48 & 10.38 & 5.77 & 2.92 \\
\hline No attack & & 67.44 & 38.60 & 33.86 & 30.90 & 30.92 & 35.62 & 38.25 & 40.38 & 41.01 \\
\hline N-sections & & 258 & 171 & 189 & 178 & 152 & 219 & 183 & 52 & 1402 \\
\hline
\end{tabular}


trunk coverage with cambioxylophagous fauna was found on trees with herbicide applied onto chain-saw cuts $(44-82 \%$ of the unoccupied sections) while on trees where herbicide was applied with a hypo-hatchet, the share of unoccupied sections reached 14-57\%. Intensity of tree dieback affected the attack of H. palliatus species. On control trees with chain-saw cuts left without herbicide application it occupied only $4.3 \%$ of the sections, on trees with chain-saw cuts treated with herbicide it attacked 2.1-25.9\% of the sections, trees after hypo-hatchet application were strongly attacked (14-47.7\%) and on trees where herbicide had been applied into a drilled hole it occupied $64.9 \%$ of sections. Attack of I. amitinus was also differentiated according to the application method used. Trees with chain-saw cuts showed lower attractiveness (both control and with herbicide application) and higher occurrence was typical for hypohatchet Roundup application. More even distribution was observed in P. chalcographus, albeit with partial preference for trees treated with the hypo-hatchet; occurrence of Cerambycidae was also the highest there (Tab. 4).

Development success of the most abundant species on blue spruces killed with herbicide varied. Altered quality of phloem created conditions suitable for lesser spruce shoot beetle $H$. palliatus that completed its development on $61.1 \%$ of the sections, however, with differences between the individual methods of herbicide application (chainsaw cuts $21.4 \%$, hypo-hatchet $60.1 \%$ and drill $98 \%$ ). I. amitinus showed high larval mortality (50.6\%) and finished its development only on $18.8 \%$ of the sections (chain-saw cuts $0 \%$, hypo-hatchet $20 \%$ ). Very low development success (7\%) was typical for P. chalcographus where high mortality at larval stage was observed ( $64.3 \%$ of sections), especially after herbicide application with hypo-hatchet $(76 \%)$ and onto chain-saw cuts (29\%) (Tab. 5).

Branches of chemically thinned blue spruces attracted P. chalcographus (22.4\%) and C. abietis (9.3\%) species. According to the method by Kula, Zabecki (1996), the attack was only scattered in most cases. Rare occurrence of I. amitinus, H. palliatus and Cerambycidae was noticed on several sections. Larvae of P. chalcographus died on a large scale (70.1\%), while C. abietis completed its development on $58.3 \%$ of the sections and flew out.

Tab. 4: Cambioxylophagous fauna on stems of blue spruces according to the time and method of herbicide (Roundup) application (\%).

\begin{tabular}{|c|c|c|c|c|c|c|c|c|c|c|c|}
\hline 记 & 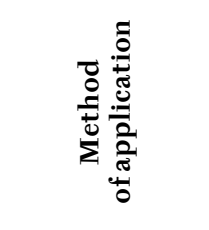 & 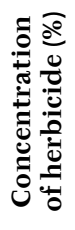 & 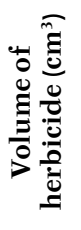 & 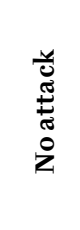 & 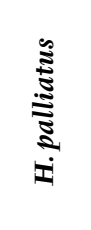 & 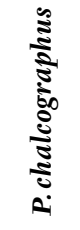 & 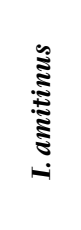 & 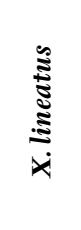 & 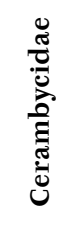 & 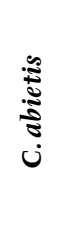 & 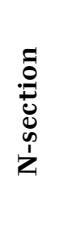 \\
\hline 20.6.2007 & Drill & 100 & 5 & 14.47 & 64.94 & 3.95 & 23.68 & 13.16 & 28.95 & 0 & 77 \\
\hline 10.10.2009 & Chain-saw cuts & 0 & 0 & 66.67 & 4.30 & 20.43 & 9.68 & 3.23 & 2.15 & 0 & 93 \\
\hline 10.10.2009 & Chain-saw cuts & 100 & 10 & 82.35 & 11.76 & 2.94 & 0 & 0 & 5.88 & 0 & 34 \\
\hline 10.10.2009 & Chain-saw cuts & 100 & 5 & 57.86 & 2.14 & 2.86 & 9.29 & 0.71 & 5.00 & 0 & 140 \\
\hline 10.10.2009 & Chain-saw cuts & 15 & 10 & 66.67 & 16.67 & 16.67 & 0 & 0 & 0 & 0 & 6 \\
\hline 10.10.2009 & Chain-saw cuts & 15 & 5 & 44.44 & 25.93 & 14.81 & 14.81 & 3.70 & 3.70 & 0 & 27 \\
\hline 10.10.2009 & Hypo-hatchet & 100 & 10 & 47.69 & 30.09 & 15.28 & 10.19 & 0 & 5.30 & 0.46 & 216 \\
\hline 10.10.2009 & Hypo-hatchet & 100 & 5 & 16.28 & 36.28 & 27.44 & 33.95 & 1.40 & 1 & 1.39 & 215 \\
\hline 10.10.2009 & Hypo-hatchet & 15 & 10 & 14.04 & 42.13 & 29.78 & 26.97 & 5.62 & 21.35 & 0.56 & 178 \\
\hline 10.10.2009 & Hypo-hatchet & 15 & 5 & 57.45 & 11.70 & 18.09 & 7.45 & 1.06 & 3.19 & 0 & 94 \\
\hline 30.6 .2010 & Chain-saw cuts & 100 & 5 & 59.26 & 12.96 & 8.64 & 17.28 & 1.23 & 0.62 & 0.62 & 162 \\
\hline 30.6 .2010 & Hypo-hatchet & 100 & 5 & 39.75 & 32.10 & 11.80 & 16.77 & 6.21 & 1.24 & 0.62 & 162 \\
\hline
\end{tabular}


Tab. 5: The proportion of sections of blue spruce killed with Roundup with developmental stages of selected species of cambioxylophagous fauna (DWCH-dried nuptial chambers, G-galleries, D G-dried galleries, L-larvae, DL-dried larvae, $P$ pupae, YB-young beetles, I-imagoes, FH-exitholes) (\%).

\begin{tabular}{lcccccccccc}
\hline \begin{tabular}{l} 
Species/Developmental \\
\multicolumn{1}{c}{ stages }
\end{tabular} & DWCH & G & DG & L & DL & P & YB & I & FH & N-sections \\
\hline Cerambycidae & 0.00 & 0.00 & 0.00 & 99.16 & 0.84 & 0.00 & 0.00 & 0.00 & 0.00 & 119 \\
Hylurgopspalliatus & 0.00 & 1.23 & 0.25 & 26.91 & 10.62 & 1.23 & 0.25 & 1.98 & 57.53 & 405 \\
Ips amitinus & 0.00 & 11.24 & 5.22 & 13.65 & 50.60 & 0.80 & 0.40 & 1.61 & 16.47 & 249 \\
Pityogenes chalcographus & 0.44 & 4.41 & 1.32 & 22.03 & 64.32 & 0.44 & 0.88 & 1.76 & 4.41 & 227 \\
Xyloteruslineatus & 0.00 & 0.00 & 0.00 & 36.59 & 0.00 & 0.00 & 0.00 & 12.20 & 51.22 & 41 \\
\hline
\end{tabular}

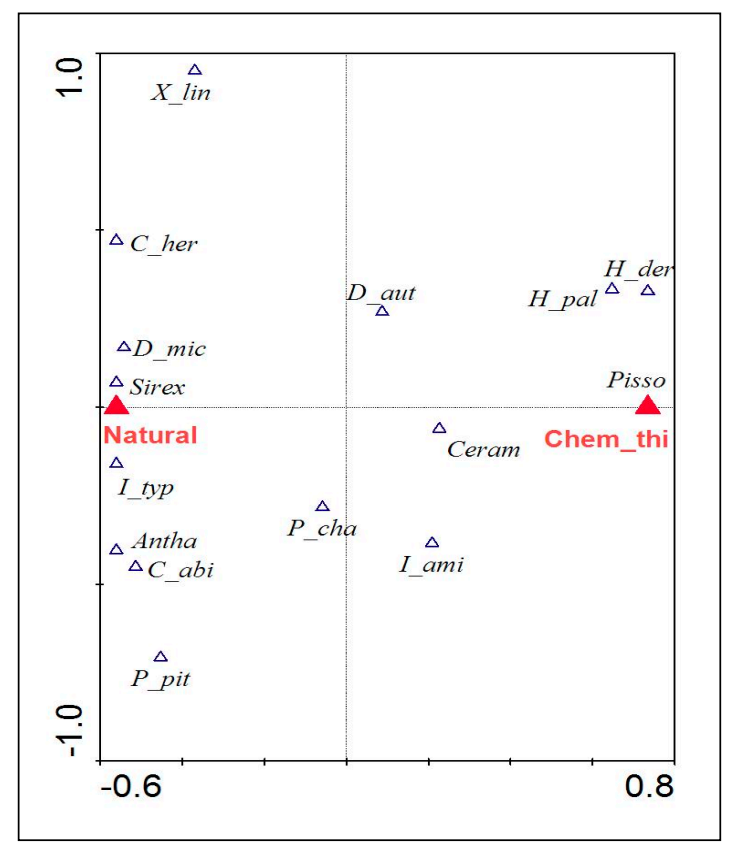

Fig. 2: Cambioxylophagous fauna on dying trees in stands with natural conditions (Natural) and after chemical thinning (Chem thi) (see Tab.3).

\section{Discussion}

Differences in phloem quality and rate of its dieback in blue spruces treated with herbicide and in naturally dying trees resulted in different synusia of cambioxylophagous species. According to the frequency of attacked sections, trees dying mainly from $D$. micans attack attracted $X$. lineatus and C. abietis (Kula et al. 2012), while after chemical thinning, $H$. palliatus and larvae of the Cerambycidae family were dominant. In commonly occurring species I. amitinus and P. chalcographus, no significant preference was found (Fig. 2). Phloem quality played a key role in development success: on herbicide-treated trees, H. palliatus completed its development, but I. amitinus and P. chalcographus died at larval stage and C.abietis did not find suitable phloem in its natural niche (tree top) as this part died back very fast, but was able to finish its development on lower branches. According to Kula, Kajfosz (2007), P. chalcographus did not complete its development on whole Norway spruces that were felled for thinning, pulled out of the stand and exposed to sunlight. On the other hand, it intensively attacked spring felling debris left in stands where slower phloem drying allowed the larvae to pupate even on the upper sides of trunks. Insignificant occurrence of $H$. palliatus, $X$. lineatus and I. amitinus was observed on Norway spruce felling debris from spring thinning. Chararas (1959) determined that low osmotic 
pressure (3-5 atm.) in bark, wood and needles of branches of Pinus sylvestris (L.) and Picea abies /L./ Karst. increases their attractiveness for $\mathrm{H}$. palliatus that concentrates on basal parts of trunks of dying trees, stumps and trees from previous autumn felling (Schroeder 1991, Schroeder, Eidmann 1993, Schroeder et al. 1999). These sources release a relatively high amount of ethanol from tissues of dying trees while the amount of released monoterpenes is low compared to the freshly felled trees (Kimmerer, Kozlowski 1982). H. palliatus inhabits parts of bark lying directly on the ground or partially impressed into soil. It prefers very moist phloem and often occurs together with X. lineatus (Ozols 1975, Lekander et al. 1977, Koch 1992, Jakuš 1998).

Structure of cambioxylophagous fauna can also be influenced by the period in which the tree was weakened and damaged (Kula, Ząbecki 2006a, 2006b, 2007). If tending felling is performed in summer period, development of cambiophagous fauna is reduced and the method of application may also affect the fauna colonizing the treated trees (Kula, Kajfosz 2006, 2007). Herbicide application in autumn and spring did not induce significant changes in the structure of blue spruce cambioxylophages with the exception of $P$. chalcographus that occurred with higher frequency on trees treated in spring. It is present in all areas where P. abies and other spruce species grow (Ratzeburg 1839, Schwerdtfeger 1970, Novák 1976, Zumr, Soldán 1981, Wood, Bright 1992). It is reported as a forest pest (Escherich 1923, Byers et al. 1988), inhabiting breakages, felling debris, branches and occasionally also young spruce stands. It is able to detect trees weakened by drought.

$H$. palliatus is a monogamous species that overwinters and swarms from early April till early May (Subansenee 1971, Lekander et al. 1977). Its flight activity decreases in June and so it does not settle on summer debris, only maturation feeding of a new generation may be seen there during autumn (Nuorteva 1956, Subansenee 1971, Ozols 1975, Lekander et al. 1977).

Temporal secondary species (Pfeffer 1995) of blue spruce fauna do not pose a threat to healthy trees (H.palliatus). They indicate changes in phloem quality and may act as food competitors, for example for Ips typographus (L.) (Norway spruce windfalls), or for P. poligraphus (standing stems of Norway spruce with broken-off whole crown) (Kula, Ząbecki 2006a, 2006b). After rapid loss of assimilatory apparatus, content of water in blue spruce phloem changes, making the conditions acceptable for $H$.palliatus.
I. amitinus frequently appeared together with I. typographus in all areas and both species reproduce at the same time (Jurc, Bojović 2004, Økland, Skarpaas 2008). From economical aspect, it is the most important pest of blue spruce. I. typographus, despite the existing strong phloem, practically did not occur on blue spruce, either dying naturally, treated with herbicides or felled. On uprooted Norway spruces, food competition between H. palliatus (bottom part of trunk) and I. amitinus (crown part of trunk) does not occur; however, on blue spruce it was observed as both species inhabited the trunks in their whole profile, I. amitinus preferring the upper and middle parts and H. palliatus the middle and butt parts of the trunks.

In spite of the fact that I. amitinus and P. chalcographus belong to significant pests, blue spruces killed with herbicide do not offer suitable substrate for their reproduction, in contrast to trees felled and cut-up in stands where outbreaks of I. amitinus are possible (Kula et al. 2011).

\section{Conclusions}

1) Chemical thinning with Roundup herbicide performed in blue spruce stands lead to development of the same cambioxylophagous fauna on the trees treated at the end and at the beginning of vegetation season, with the exception of higher share of P. chalcographus after spring application.

2) Phloem quality created conditions suitable for successful development of $\mathrm{H}$. palliatus, while species P. chalcographus and I. amitinus showed high mortality at larval stage.

3) C. abietis completed its development only on thicker branches; tree tops were not colonized due to fast phloem dieback.

4) Bark beetle fauna on chemically thinned blue spruces showed a high share of H.palliatus, in contrast to fauna of naturally-dying trees with prevalence of D. micans and X.lineatus.

5) Blue spruces treated with Roundup do not offer conditions suitable for outbreaks of economically significant bark beetles.

\section{Acknowledgment}

This research was supported from the project MSM 62156489 and by regional companies - Netex s. r. o., Děčín, Nadace ČEZ a. s., Prague, and Lafarge cement a. s., Čížkovice. 


\section{References}

BALCAR, V. 1986: Tolerance dřevin v juvenilním stádiu $\mathrm{k}$ průmyslovým imisím [Tolerance of species of trees in the juvenile stage to industrial air pollution]. Práce VÚLHM, 69, Jíloviště-Strnady, VÚLHM, 137-165.

Byers, J.A., Birgesson, G., Löfovist, J., BergSTRÖM., G. 1988: Synergistic pheromones and monoterpenes enable aggregation and host recognition by a bark beetle. Naturwissenschaften, 75: 153-155.

Escherich, K. 1923: Die Forstinsekten Mitteleuropas II. Berlin, Germany, Paul Parey, $663 \mathrm{pp}$.

Chararas, C. 1959: Variations of osmotic pressure in conifers, as a factor determining penetration by Scolytidae. Comptes Rendus Hebdomadaires des Siances de I'Acadgmie des Sciences, Paris, 249 (9): 1407-1410.

JAKUŠ, R. 1998: Patch level variation on bark beetle attack (Col., Scolytidae) on snapped and uprooted trees in Norway spruce primeval natural forest in endemic conditions: species distribution. Journal of Applied Entomology, 122(2/3): 65-70.

Jirgle, J., KuČera, J., Tichý, J., Materna, J. 1983: Poškození lesů v Jizerských horách imisemi [Injury of forests by pollution in Jizerské hory Mts.]. Zprávy lesnického výzkumu, 28 (1): $16-24$.

JuRc, M., Bojović, S. 2004: Bark beetle outbreaks during the last decade with special regard to the eight-toothed bark beetle (Ips amitinus Eichh.) outbreak in the Alpine region of Slovenia. In: CsóKA, G., Hirka, A., Koltay, A. (eds.): Biotic damage in forests. Proceedings of the IUFRO (WP 7.03.10). Symposium held in Mátrafüred, Hungary, September 12-16, 2004, 85-95.

Kimmerer, T.W., KozlowsKi, T.T. 1982: Ethylene, ethane, acetaldehyde, and ethanol production by plants under stress. Plant Physiology, 69 (4): 840-847.

Косн, K. 1992: Die Käfer Mitteleuropas. Ökologie, vol. 3. Krefeld, Germany, Goecke \& Evers, $365 \mathrm{pp}$.

Kubelka, L., Karâsek, A., Rybár̆, V., Badalík, V., SLODIČÁK, M. 1992: Obnova lesa v imisemi poškozené oblasti severovýchodního Krušnohoři [Forest regeneration in area damage by pollution in NE Krušné hory Mts.]. Praha, MZe ČR, $133 \mathrm{pp}$.

Kudela, M., Wolf, R. 1963: Podíl podkorního a dřevokazného hmyzu na odumírání smrku a borovice v porostech poškozených průmyslovými exhalacemi [The proportion of bark and wood-boring insects on the death of spruce and pine in forests damaged by industrial emissions]. Sb.les.fak. VŠZ Praha, 6: 157-187.

Kula, E., Kajfosz, R. 2006: Osídlování smrkového těžebního odpadu z jarní prořezávky kambiofágy ve vyšších polohách Beskyd [Colonization of spruce logging debris from spring cleaning by cambioxylophagous insect at higher locations of the Beskids]. Beskydy, 19: 171-176.

Kula, E., Kajfosz, R. 2007: Colonization of spruce logging debris from summer and autumn cleaning by cambioxylophagous insect at higher locations of the Beskids. Beskydy, 20: 193-198.

Kula, E., Kajfosz, R., Polívka, J. 2009: Cambioxylophagous fauna of blue spruce (Picea pungens Engelmann) in the Krušné hory Mts. (Czech Republic). Beskydy, 2 (2): 149-156.

Kula, E., Kajfosz, R., Polívka, J. 2011: Cambioxylophagous fauna developing on logging residues of blue spruce (Picea pungens Engelmann). Journal of Forest Science, 57 (1): 24-33.

Kula, E., Kajfosz, R., Polívka, J. 2012: Dendroctonus micans (Kug.) a kambioxylofágní fauna smrku pichlavého (Picea pungens Engelm.) ve stř̌ední Evropě (Krušné hory, Česká republika) [Dendroctonus micans (Kug.) and cambioxylophagous fauna of blue spruce (Picea pungens Engelm.) in Central Europe]. Zprấvy lesnického výzkumu, 57: 378-386.

Kula, E., Kajfosz, R., ZąbeKi, W. 2006: Kambioxylofágové smrkových zlomů a odlomů [Cambioxylophages of spruce stem breaks and broken-off parts of trees]. Lesnická práce, 85 (8): 22-23.

Kula, E., ZABECKI, W. 1996: Synuzie kambioxylofágů na smrcích podúrovně [Synusia of cambioxylophages on subdominant trees of Norway spruce]. Zpravodaj Beskydy, 75 (8): 213-220.

KulA, E., ZABECKI, W. 1997: Lightning-stroken areas as the centres of bark-beetle-infested patches within spruce stands. Sylwan, CXLI (8): 89-97 (in Polish).

Kula, E., ZAвECKI, W. 2006a: Spruce windfalls and cambioxylophagous fauna in an area with the basic and outbreak state of Ips typographus. Journal of Forest Science, 52 (11): 497-509.

Kula, E., ZĄвECKI, W. 2006b: Jarní aspekt v osídlení kmene smrkových vývratů kambiofágy [Spring aspect in the colonization of the stem of spruce windthrows by cambioxylophagous insect]. Beskydy, 19: 177-184. 
Kula, E., ZAвеCKI, W. 2007: Synuzie kambioxylofágů zimních vývratů $\mathrm{v}$ prvním roce po polomu [The synusia of cambioxylophages of winter windfalls in the first year after a windbreak]. Beskydy, 20: 199-210.

Lekander, B., Bejer-Petersen, B., Kangas, E., BAKKE, A. 1977: The distribution of bark beetles in the Nordic countries. Acta Entomologica Fennica, 32: 1-37.

Novák, V. 1976: Atlas of insects harmful to forest trees. Vol. 1. Amsterdam, Elsevier Scientific Publishing Company, 125 pp.

Nuorteva, M. 1956: Über den FichtenstammBastkäfer, Hylurgops palliatus Gyll., und seine Insektenfeinde. Acta Entomologica Fennica, 13, 118 pp.

ØKLAND, B., SKARPAAs, O. 2008: Draft pest risk assessment report on the small spruce bark beetle, Ips amitinus. Commissioned report from Norwegian Forest and Landscape Institute [Oppdragsrapport fra Skog og landskap], 10: 20 pp.

OzoLs, G. E. 1975: Investigating the attractants of the engraver beetle in natural surroundings. Proc. of the $8^{\text {th }}$ International Plant Protection Congress, 8: 49-52.

Pfeffer, A. 1995: Prvotní (primární) a druhotní (sekundární) hmyzí škůdci [Primary and secondary insect pests]. Lesnická práce, 74(1): 15-16.

Pop, M., Kula, E., Mañas, P., Kajfosz, R. 2010: Chemical thinning in blue spruce (Picea pungens Engelm.) stands and its effects on cambioxylophagous fauna. Journal of Forest Science, 56: 225-235.

RatzebuRG, J.T.C. 1839: Die Forst-Insekten, Erster Theil, Die Käfer. Berlin.

Schroeder, L.M., EidmanN, H.H. 1993: Attacks of bark- and wood-boring Coleoptera on snow-broken conifers over a two-year period. Scandinavian Journal of Forest Research, 8 (2): 257-265.

Schroeder, L.M., Weslien, J., Lindelöw, A., LindHE, A. 1999: Attacks by bark- and woodboring Coleoptera on mechanically created high stumps of Norway spruce in the two years following cutting. Forest Ecology and Management, 123 (1): 21-30.

SCHROEDER, L.M. 1991: Attraction of some scolytids and associated beetles to the host volatiles (-pinene and ethanol). In: BaranchiKov, Y.N., Mattson, W.J., Hain, F.P., Payne, T.L. (eds.): Forest insect guilds: patterns of interaction with host trees, USDA Forestry Service General Technical Report, NE-153, 393-394.
SCHWERDTFeger, F. 1970: Waldkrankheiten. Dritte Auflage. Verlag Paul Parey, Hamburg und Berlin, 509 pp.

SubANSEnEe, W. 1971: Flight period and emergence in Denmark of the adult bark beetle Hylurgops palliatus Gyll. (Coleoptera, Scolytidae). Arsskrift, Kongelige Veterinaer- og Landbohoiskole, 114-113

ŠIKA, A. 1976: Růst smrku pichlavého v lesních porostech [The growing of Picea pungens in the forest stands]. Zprávy lesnického výzkuтu, 22 (2): 8-12.

Šrámek, V., Hadaš, P., Lachmanová, Z., FadRhonsová, V., Vortelová, L., LomskÝ, B., KulHAVY̌, J. 2008: Imisní zatížení Krušných hor. [Air pollution in the Krušné hory Mts.] In: SlodičÁK, M., Balcar, V., Novák, J., Šrámek, V., Borưvka, L., Derco, D., Detz, E., Fadrhonsová, V., Fiala, P., Hadaš, P., Hajnala, M., Havránek, F., Hellebrandová, K., Humplík, J., Hynek, V., Jarský, V., Jurásek, A., KacÁlek, D., KañÁ,, J., Kmínek, A., Kobliha, J., Kula, E., Kulhavý, J., Lachmanová, Z., Lehner, J., LeHNEROVÁ, L., LEHEČKA, J., LEUGNER, J., LOMSKÝ, B., Martincová, J., MatěJKa, K., Mauer, O., MenŠík, L., Mutínskŕ, V., NÁrovcová, J., NÁrovec, V., Navrátil, P., Novotný, R., Nový, L., PéničKa, L., Pospíšil, J., Pulkrab, K., SKoblík, J., Sloup, M., Smejkal, J., Sychrava, J., ŠišĀK, L., VORTELOVÁ, L., VysLYŠEL, K. Lesnické hospodařní v Krušných horách. Edice grantové služby LČR, číslo 03: 45-70.

TESAR̆, V. 1981: Růst dřevin v obnovním cíli při silném ohrožení imisemi na Trutnovsku [Growth of tree species in forest restoration under heavy threat pollution at Trutnov region]. Zprávy lesnického výzkumu, 26 (2): 16-20.

TerBraAk, C. J. F., Šmilauer, P. 2002: Canoco Reference Manual and CanoDraw for Windows User's Guide: Software for Canonical Community Ordination (version 4.5). Ithaca, NY: Microcomputer Power: 500 pp.

WoOD, S.L., BRIGIT, D.E. JR 1992: A catalogue of Scolytidae and Platypodidae (Coleoptera), Part 2: Taxonomic index. Great Basin Naturalist Memoirs, $1553 \mathrm{pp}$.

Zumr, V., Soldan, T. 1981: Reproductive cycle of Ips typographus, I. amitinus and Pityogenes chalcographus (Coleoptera, Scolytidae). Acta Entomologica Bohemoslovaca, 78 (5): 280-289. 
